\title{
TSC2 Gene Mutation
}

National Cancer Institute

\section{Source}

National Cancer Institute. TSC2 Gene Mutation. NCI Thesaurus. Code C118399.

A change in the nucleotide sequence of the TSC2 gene. 